Науковий вісник Дьвівського національного університету ветеринарної медицини та біотехнологій імені С.3. Гжицького

\author{
Scientific Messenger of Lviv National University \\ of Veterinary Medicine and Biotechnologies
}

\title{
Practical experience and perspectives in solving the problem of complex use of bone raw materials at meat industry
}

\author{
L. Moldavanova, U. Drachuk, I. Basarab, I. Romashko, B. Halukh, N. Krynska \\ Stepan Gzhytskyi National University of Veterinary Medicine and Biotechnologies Lviv, Ukraine
}

\section{Article info}

Received 17.09.2018

Received in revised form 15.10 .2018

Accepted 16.10.2018

Stepan Gzhytskyi National University of Veterinary Medicine and Biotechnologies Lviv, Pekarska Str., 50, Lviv, 79010, Ukraine.

Tel.: + 38-067-732-58-15 E-mail:tmmozv@ukr.net

\begin{abstract}
Moldavanova, L., Drachuk, U., Basarab, I., Romashko, I., Halukh, B., \& Krynska, N. (2018). Practical experience and perspectives in solving the problem of complex use of bone raw materials at meat industry. Scientific Messenger of Lviv National University of Veterinary Medicine and Biotechnologies. 20(90), 69-74. doi: 10.32718/nvlvet9014
\end{abstract}

The article analyzes the complex of processing of bone raw materials in the production. The project of complex processing of recycled raw materials of meat processing enterprises is offered. It was recommended and substantiated promising directions for the recycling of raw materials for the production of bone flour, bone food animal fats and dry bouillon concentrate. The problems of rational use of recycled resources are shown on the example of processing of raw bones using the lines Y8-FLK for shredding, transportation, fat separation, drying and grinding of the finished product. Products of bone processing on the lines of Y8-FLK-edible bone fat and bone flour. The production of concentrated bone broth is carried out in K7-FV3-B machines, which provide for the continuous removal of fat and broth. The drying of the broth is provided in the drying plant A1-FMU with the use of the process in the vibro-boiling layer of inert material from fluoroplastic cubes. Drying in this way allows to get an animal protein that retains all the nutritional qualities. The dry protein was mixed with flavored fat, dried chopped vegetables and spices. The main factor in the amount of removal of protein components from the bones is the type of raw material - raw bone or bone residue after mechanical admission by pressing. The maximum removal of the protein components was obtained using a bone remnant after mechanical supplementation. According to the project, proposed on the 1st floor of the annex was provided department for the receiving of dry bone, production of bone meal and its storage, on the II-th - a division of bulging of bone fats, on the III-th - a branch of drying broth, the preparation of dry broth with spices, cleansing of bone fat. The project provides for the processing of bone raw materials in the amount of $8 \mathrm{t} / \mathrm{s}$. The technology of processing bone raw materials was carried out as follows: on the lines of Y8-FLK, also - lumbar bones (skull bones, shoulder blades, femur bones), ribbones, vertebrae - $6 \mathrm{t} / \mathrm{s}$., in machines K7-FV3-B - tubular bones and fists $(2 \mathrm{t} / \mathrm{s})$. The project allows solving the problem of complex bone processing: production of bone fat, bone meal, dry bouillon.

Key words: Raw bones, skimmed bones, bone fat, bone meal, dry bouillon concentrate.

\section{Практичний досвід і перспективи у вирішенні проблеми комплексного використання кісткової сировини на підприємствах м'ясної галузі}

\author{
Л.К. Молдаванова, У.Р. Драчук, І.М. Басараб, І.С. Ромашко, Б.І. Галух, Н.В. Кринська \\ Львівський національний університет ветеринарної медицини та біотехнологій імені С.3. Гљсицкого, \\ м. Львів, Україна
}

У статті проведено аналіз комплексної переробки кісткової сировини на виробництві. Запропоновано проект комплексної переробки вторинної сировини м'ясопереробних підприємств. Рекомендовані та обтрунтовані перспективні напрямки переробки вторинної сировини з виробництва кісткового борошна, кісткових харчових тваринних жирів, сухого бульйонного концентрату. Проблеми раџіонального використання вторинних ресурсів показано на прикладі переробки сирих кісток із використанням ліній Я8-ФЛК для подрібнення транспортування, жировідділення, сушіння і подрібнення готового продукту. Продукти переробки кісток на лініях Я8-ФЛК - харчовий кістковий жир і кісткове кормове борошно. Отримання концентрованого кісткового бульйону здійснено в апаратах К7-ФВЗ-В, які передбачають безперервне відведення жиру $і$ бульйону. Сушіння бульйону передбачено у сушильній установиі АІ-ФМУ із застосуванням процесу у віброкип'ячому шарі інертного матеріалу із фторопластових кубиків. 
Сушіння таким способом дозволяє отримати тваринний білок, який зберігає всі харчові якості. Сухий білок змішували із ароматизованим жиром, сухими подрібненими овочами і спеціями. Основним фактором кількості видалення білкових компонентів із кісток є вид вихідної сировини - сира кістка або кістковий залишок після механічного дообвалення методом пресування. Максимальне вилучення білкових компонентів одержали при використанні кісткового залишку після механічного дообвалення.

Ключові слова: Сирі кістки, знежирені кістки, кістковий жир, кісткове борошно, сухий бульйонний концентрат.

\section{Вступ}

Основною сировиною м'ясної галузі промисловості являється м'ясо забійних тварин. В промисловому значенні м'ясом називають скелетні м'язи разом 3 кістками скелета.

У технологічній практиці тканини, з яких складається м'ясо, прийнято класифікувати за промисловим значенням. В цьому розумінні м'ясо це наступні тканини: м'язева, жирова, сполучна, хрящова, кісткова i кров. У складі м'яса кількісне співвідношення цих тканин коливається в широких межах і залежить від виду, породи, статі, віку, вгодованості, характеру відгодівлі тварин а також в процесі промислової переробки від ступеня звільнення м'яса від тканин другорядного значення (сполучної тканини, хрящів, кісток) (Bozhko et al., 2016; Kryzhska, 2017; Ukrainets et al., 2017; Tishkina et al., 2018).

У м'ясі забійних тварин кількісне співвідношення тканин становить: м'язева тканина - 50-70\%, сполучна - 9-14\%, жирова - 3-20\%, кісткова і хрящова - 15$22 \%$.

Кількісне співвідношення тканин в м'ясі визначає його хімічний склад, поживну цінність і властивості м'яса. Найбільшою поживною цінністю володіє м'язева тканина. Вона містить: воду, білки $(16,5-$ 20,9\%), екстрактивні речовини, ліпіди, мінеральні речовини, вітаміни.

Кісткова тканина відрізняється розвиненою міжклітинною речовиною і складається із органічних, неорганічних речовин і води. В міжклітинній речовині розташовані кісткові клітини і проходять кровоносні судини.

У кістках розрізняють зовнішній і внутрішній шари. Зовнішній шар складається із щільної речовини, внутрішній - 3 губчастої речовини.

Ці речовини, щільна і губчаста, побудовані із закостенілих пластинок, які утворені невеликими пучками колагенових волокон. У губчастій речовині ці пластини розташовані не так впорядковано, як в щільній речовині, в результаті утворюють численні пори. В порах міститься червоний кістковий мозок.

Головним органічним компонентом основної речовини кістки $\epsilon$ колаген. Він становить $20 \%$ до маси кісткової тканини або 40\% до її об'єму.

Кістковий мозок містить: ліпідів 84-95\%, білків 13\%, вода 4-12\%. До складу ліпідів входять: 99,5\% тригліцеридів, 0,2\% фосфатидів, 0,32\% холестерину. Кістки скелету забійних тварин, відповідно до особливостей структури, характеру технологічної обробки i напрямку використання, поділяють на: трубчасті (кістки кінцівок), пластинчасті (кістки черепа, лопатки, тазові кістки), кістки ребер, хрящів.

Аналіз хімічного складу кісток забійних тварин свідчить, що найбільшу кількість білків містять трубчасті кістки (17-23\%), кулаки - до 21\%, кількість кісткового жиру відповідно - (13-24\%) і (18-23\%) (Cherevko et al., 2010).

Кістки забійних тварин зовні вкриті сполучнотканинною оболонкою - окістям, а поверхня кулаків хрящовим шаром. Хрящова тканина складається із аморфної (основної) щільної речовини. Залежно від виконуваної функції хрящі мають різну будову. Розрізняють гіаліновий (склоподібний), волокнистий (сполучнотканинний) і еластичний хрящі.

Хрящова тканина, в порівнянні 3 кістковою, містить більше води і менше мінеральних речовин. Найважливіші складові основної речовини хрящів є хондромукоїди, мукополісахариди (хондроітинсульфатна кислота), колаген, а також інші органічні і мінеральні речовини.

Слід зазначити, що переробка кісткової сировини на сучасних підприємствах м'ясної галузі знизилась, оскільки обмежена або відсутня комплексна переробка цієї сировини (Fajvishevskij, 2013). Це пояснюється обмеженістю фінансових вкладень, а також зростанням цін на енергетичні ресурси, які суттєво залучені до переробки кісткової сировини (Ianovych and Kupchuk, 2014). Вирішення цієї проблеми можливе завдяки розробці проектної документації 3 комплексної переробки кісткової сировини, із використанням у технології сучасного енергозберігаючого технологічного обладнання та раціонального використанням виробничих площ (Volik et al., 2011; Fajvishevskij, 2012).

\section{Матеріали і методи досліджень}

Проектом передбачено переробку кісткової сировини в кількості 8 т/зм. Технологію переробки кісткової сировини здійснювали наступним чином:

- На лініях Я8-ФЛК - пластинчасті кістки (кістки черепа, лопатки, стегнові), реберні кістки, хребці $6 \mathrm{~T} / 3 \mathrm{M}$.

- В апаратах К7-ФВ3-В - трубчасту кістку та кулаки (2 т/3м).

Розроблено проект цеху комплексної переробки кісткової сировини із планами $1 . . .3$-го поверхів цеху, 3 відділенням виробництва сухого бульйону (Рис. 1...3). 


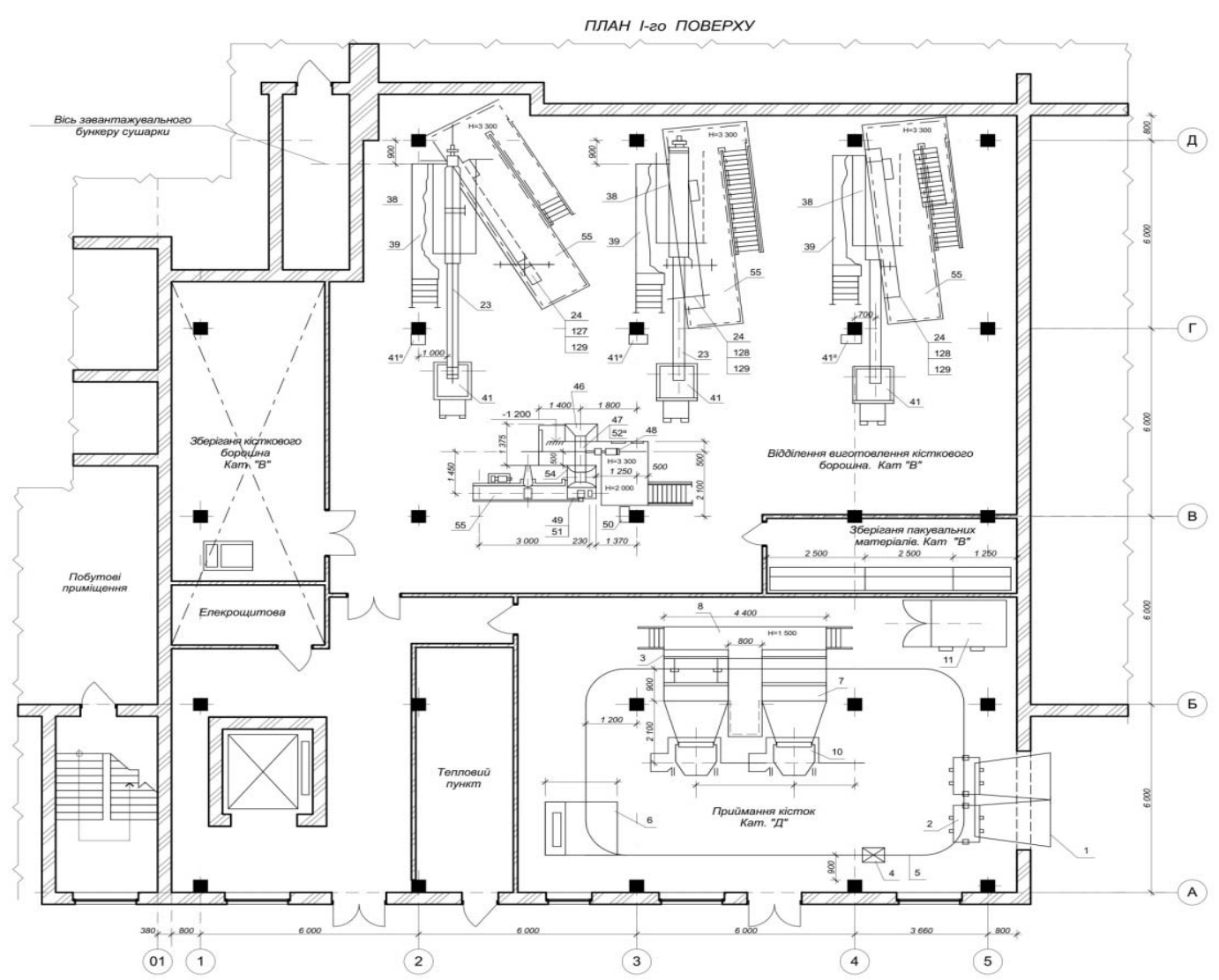

Рис. 1. План першого поверху цеху комплексної переробки кісткової сировини

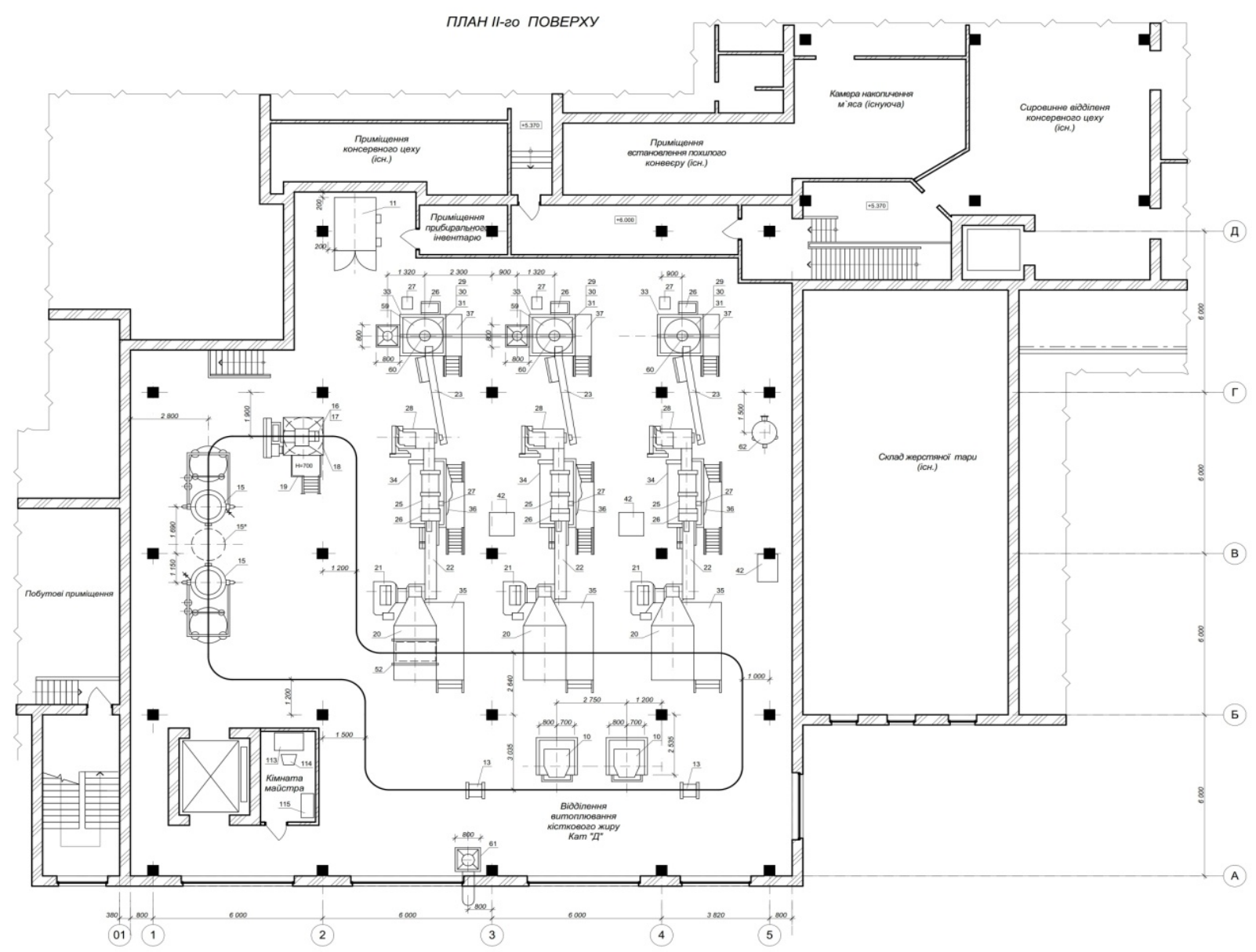

Рис. 2. План другого поверху цеху комплексної переробки кісткової сировини 


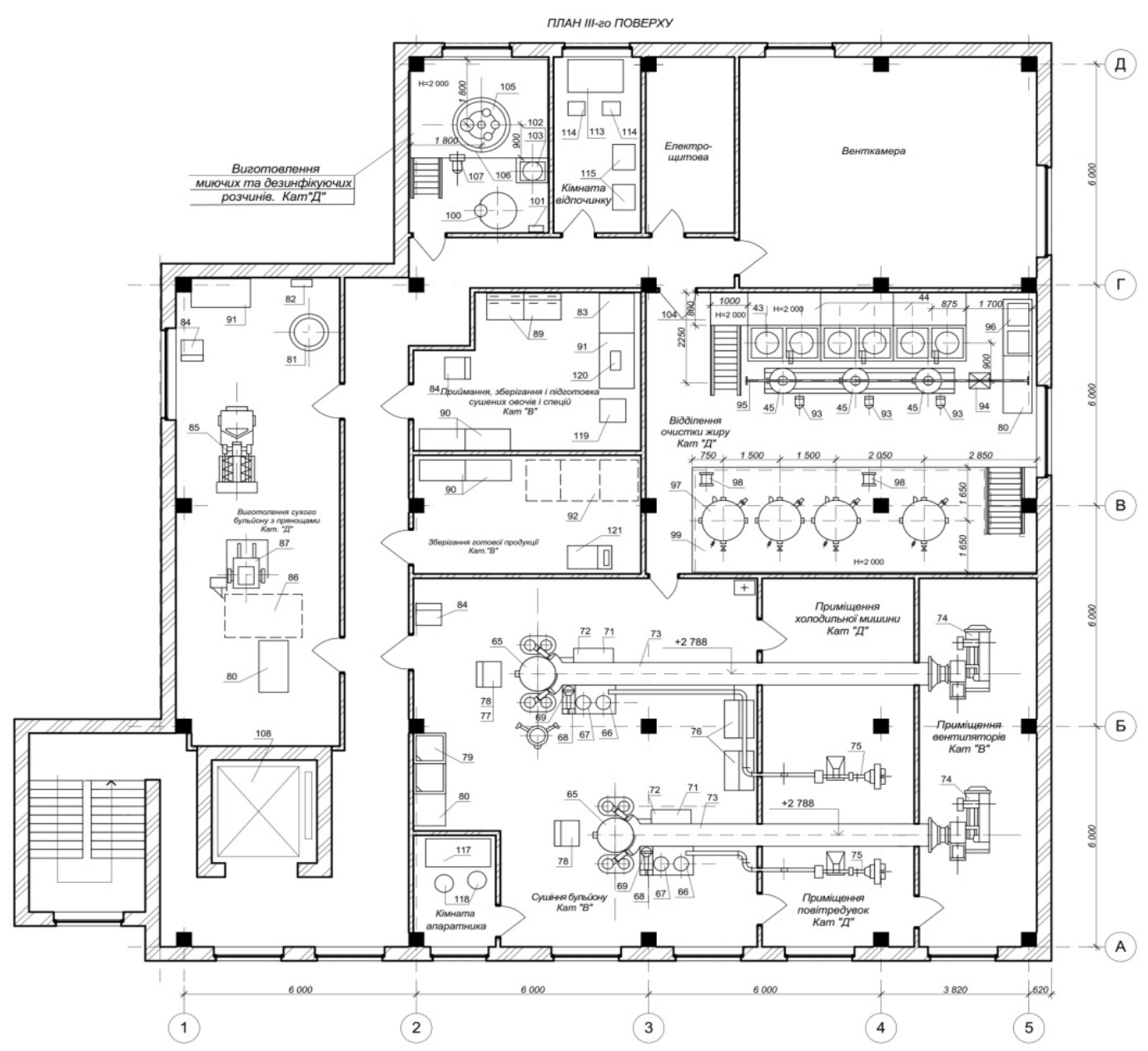

Рис. 3. План третього поверху цеху комплексної переробки кісткової сировини

Проект заплановано на типовому м'ясокомбінаті у 3-х поверховій прибудові, яка розташована між цехом витоплювання кісткових жирів, ковбасним і консервним цехами.

\section{Результати та їх обговорення}

За результатами досліджень, запропоновано на Iму поверсі прибудови було передбачено відділення приймання сухої кістки, виробництва кісткового борошна і його зберігання, на II-му - відділення витоплювання кісткових жирів, на III-му - відділення сушіння бульйону, приготування сухого бульйону 3 прянощами, очищення кісткових жирів.

Сирі кістки, призначені для переробки, подають у відділення приймання для зважування, промивання, стікання. Вертикальними підйомниками сировина подається на II поверх для подальшої переробки.

Для покращення завантажувальнорозвантажувальних робіт в проекті запропоновано пристрій для саморозкриття ковшів.

Кістки (трубчасті і кулаки) із підйомників вивантажують, залежно від призначення в кошики апаратів К7-ФВ3-В, або в саморозкриваючі ковші на лінії Я8ФЛК, які призначені для подрібнення, транспортування, жировідділення, сушіння і подрібнення готового продукту. Ковші і кошики переміщують за допомо- гою електричної талі. Кінцевим продуктом є харчовий кістковий жир і кісткове кормове борошно.

Сирі кістки із ковша подають на приймальний стіл звідки поступають у подрібнювач, де подрібнюють на шматки 20-50 мм. Подрібнена кістка елеватором поступає у жировідокремлювач для нагрівання і часткового знежирення. Виділений бульйон з жиром стікає у збірник, звідки насосом перекачується у відстійник для відстоювання і очищення жиру.

Для повторного кісткова сировина із жировідокремлювача подається у вовчок з діаметром отворів решітки 30 мм. В результаті у вовчку випаровується $1,5-2 \%$ вологи, а температура маси знижувалась до $65^{\circ} \mathrm{C}$. Подрібнена сировина елеватором подається в бункер-накопичувач 3 підігрівом і порціями завантажується у центрифугу для оброблення парою під тиском 0,3-0,4 мПа впродовж 3-4 хв. Фугат із центрифуги відводиться в збірник жиромаси, далі - насосом у відстійник.

Кістки після центрифугування спуском подають на I поверх, де з допомогою елеватора транспортується в сушильний агрегат для висушування до вологості відповідно до вимог стандарту.

Надалі, сухі кістки елеватором подають на дробильно-просіювальний агрегат, а готове кісткове борошно - норією на вагове дозування і фасування. 
Фугат із відстійників самопливом поступає в сепаратор для остаточного очищення. Очищений жир насосом подається у відстійники, для накопичення до передачі в ємкості для безтарного зберігання.

Кістки, що відповідають вимогам державного стандарту і призначені для виробництва сухих бульйонів подають на II-ий поверх згідно схеми (рис. 2). Для їх теплової обробки, запроектовано два апарати для витоплювання жиру із кісток К7-ФВ3-В. Відповідно до цього теплова обробка кісток проводиться гострою парою. Отриманий бульйон і жир поступає у відстійник, розташований на III-му поверсі.

Технологія передбачає перекачування жиру після відстоювання у інші відстійники для подальшого очищення (рис. 1-3). Бульйон, що залишився у відстійниках, після відстоювання висушують. Сушіння бульйону проводять на сушильній установці А1-ФМУ (2 одиниці).

Вартий уваги той факт, що установка призначена для сушіння рідких харчових продуктів у віброкиплячому шарі інертного матеріалу. Запропоновано використовувати як інертний матеріал фторопластові кубики.

Принцип роботи установки А1-ФМУ полягає у наступному: рідкий бульйон за допомогою форсунок розпиляється у вигляді плівки, покриваючи гранули, у сушильній камері у віброкиплячому шарі, миттєво висушується, відділяється від гранул і виноситься відпрацьованим повітрям в циклон. В кінцевому результаті одержують сухий тваринний білок, що зберігає всі харчові якості.

Наступним етапом є обробка жиру. Жир, призначений для виробництва сухого бульйону з прянощами, нагрівають у котлі, добавляють сухі подрібнені овочі і спеції відповідно рецептурі і подають в мішалку де змішували всі компоненти.

Компоненти завантажують в мішалку за такою послідовністю: сіль, цукор, сухий білок, глютамінат натрію (перемішують до рівномірного розподілу) потім додають ароматизований жир і знову перемішують до отримання розсипної маси, яку подають на фасування.

Для фасування бульйону запропоновано використовувати автомат ВТН-33А. Маса однієї упаковки 50 г. Для завантаження автомата використовують підйомник. Проект передбачає подачу готової продукції з III-го поверху за допомогою ліфта.

Отриманий в апаратах К7-ФВ3-В вологий кістковий напівфабрикат доцільно частково використовувати після подрібнення на силовому подрібнювачі в якості добавки до отриманої на лінії Я8-ФЛК кісткової суміші для сушіння в сушильному агрегаті 3 метою отримання кісткового борошна, або направляти у цех технічних фабрикатів. Подача вологого кісткового напівфабрикату з II-го поверху на I-й здійснюється спуском у спеціальні контейнери.

Запропоновано проект цеху, який дозволяє здійснити комплексну переробку кісток: виробництво кісткового жиру, кісткового борошна, сухого бульйону. Асортимент запроектованого цеху наступний:

1. Сухий бульйон з прянощами - 0,120 т/3м, в тому числі сухого бульйону 30 кг/зм;
2. Жир кістковий $-1,12$ т/3м;

3. Кісткове борошно $-2,580 \mathrm{~T} / 3 \mathrm{M}$.

На досушування в ЦТФ направлялось 1,140 т/3м вологого кісткового напівфабрикату.

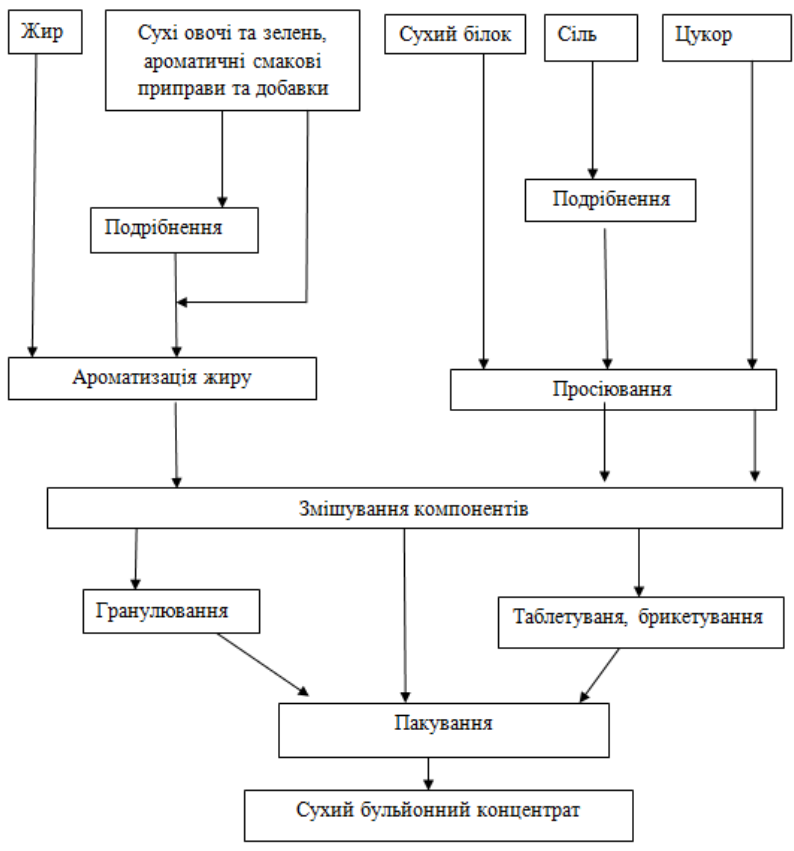

Рис. 4. Технологічна схема виробництва сухого бульйонного концентрату

На сьогоднішній день, питання раціонального i ефективного використання кісток забійних тварин, залишається бути актуальним і проблемним. Слід відмітити, що міжнародне визнання отримали технологія і обладнання з механічного дообвалювання кісток методом пресування. Ця технологія успішно використовується за кордоном. В Україні такі технології використовують досить обмежено. Однак, існуюча технологія дозволяє забезпечити різний рівень видалення білкових компонентів із кісток. Важливим фактором при цьому є вид вихідної сировини, а саме переробка сирої кістки чи кісткового залишку після механічного дообвалювання методом пресування. При використанні сирих кісток і апаратів для видалення жиру із кісток К7-ФА2-Ж вихід білкових компонентів в сухому вигляді складав 2,5-3\% до маси сировини. При використанні кісткового залишку після механічного дообвалювання, вихід білкових компонентів в сухому вигляді, склав $8 \%$.

Отже, технологія, що передбачає механічне дообвалення кісток, забезпечує більш повне видалення білкового компонента (більше ніж в 2 рази).

Сухий кістковий напівфабрикат це розсипчаста маса від білого до жовтого кольору без стороннього смаку і запаху. Він містить вологи не більше 10\%, жиру не більше 4\% і білка $83 \%$ (за нітрогеном), $\mathrm{pH}$ $6,5-6,8$.

Аналіз амінокислотного складу сухого білкового напівфабрикату отриманого із сирих кісток або кісткового залишку свідчать про наявність в ньому всіх незамінимих амінокислот незалежно від виду вихідної сировини. Для продукту, виробленого із сирої кістки 
характерний низький вміст оксипроліну, проліну, гліцину, а також високе співвідношення незамінимих і замінимих амінокислот (1:3) порівняно до аналогів із кісткового залишку (1:4, 1:5) (Fajvishevskij et al., 2008).

Сухий білковий напівфабрикат використовується для виробництва широкого асортименту харчової продукції. Найбільш розповсюджений напрямок використання - це виробництво ароматизаторів. Це пов'язано 3 тим, що даний продукт містить значну кількість глютамінової кислоти, натрієва сіль якої являється носієм м'ясного смаку і через це використовується в усьому світі як ароматизатор. Крім того, сухий білковий напівфабрикат містить також екстрактивні речовини (наприклад креатинін), які позитивно впливають на смакові якості виробів.

Сухий білковий напівфабрикат використовують для виробництва продуктів харчування функціонального призначення, наприклад сухі сніданки для профілактики i лікування порушень фосфорнокальцієвого обміну в організмі людини, хворих остеопорозом (Fajvishevs'kij, 1997). Високу жироемульгуючу і стабілізуючу можливість сухого білкового напівфабрикату використовують для виробництва паштетів, м'ясних паст (Litvinova, 2004). Перспективними напрямками використання цього продукту $є$ виробництво хлібобулочних і кондитерських виробів.

\section{Висновки}

Враховуючи вищевикладене, можна зробити висновок, що повна і комплексна переробка кісткової сировини на підприємствах м'ясної галузі, із використанням сучасної технології і енергозберігаючого обладнання дозволяє забезпечити ефективну і раціональну переробку сировини, проводити наукові дослідження в цій галузі, з метою розширення асортименту продуктів функціонального призначення.

Перспективи подальших досліджень. Подальші дослідження будуть спрямовані на визначення показників якості та безпеки продукту отриманого за вдосконаленою технологією.

\section{References}

Bozhko, N.V., Pasichniy, V.M., \& Bordunova, V.V. (2016). Meat-containing cooked sausage containing the meat of a duck. Scientific Messenger LNUVMBT named after S.Z. Gzhytskyj, 18, 2(68), 143-146. doi: 10.15421/nvlvet6829.

Cherevko, A.Y., Holovko, N.P., Polevych, V.V.., Chuiko, L.O., Serik, M.L., \& Holovko, T.M. (2010). Vykorystannia produktiv pererobky kharchovoi kistky $\mathrm{u}$ tekhnolohii produktiv spetsialnoho pryznachennia. Kharkiv: NTU "KhPI" (in Ukrainian).

Fajvishevs'kij, M.L. (1997). Ispol'zovanie mineral'noj chasti kosti ubojnyh zhivotnyh v produktah lechebnoprofilakticheskogo naznachenija. Dokl. Ros akad. s.-h nauk, 3, 40-44 (in Russian).

Fajvishevskij, M.L. (2012). Pererabotka nepishhevyh othodov mjasopererabatyvajushhih predprijatij. Mjasnye tehnologii, 3, 42-45 (in Russian).

Fajvishevskij, M.L. (2013). Metody pererabotki pishhevoj kosti. Mjasnye tehnologii, 11, 52-55 (in Russian).

Fajvishevskij, M.L., Pashhenko, L.P., \& Lisina, T.N. (2008). Prespektivy ispol'zovanija kosti ubojnyh zhivotnyh. Mjasnaja industrija, 6, 57-59 (in Russian).

Ianovych, V.P., \& Kupchuk, I.M. (2014). Obhruntuvannia tekhnolohii ta obladnannia dlia vyrobnytstva kistkovoho boroshna. Zb. nauk. pr. Vinnytskoho NAU Seriia: tekhnichni nauky, 1(84), 177-181. http://nbuv.gov.ua/UJRN/znpvnutn_2014_1_28 (in Ukrainian).

Kryzhska, T. (2017). Research of efficiency of use of bacterial preparations on the quality characteristics of delicatessen products. Scientific Messenger LNUVMBT named after S.Z. Gzhytskyj, 19(75), 7680. doi: 10.15421/nvlvet7515.

Litvinova, E.V. (2004). Pashtety dlja funkcional'nogo pitanija. Mjasnaja industrija, 5, 25-26 (in Russian).

Tishkina, N.M., Lieshchova, M.O., \& Iesina, E.V. (2018). Microstructural analysis of the quality of forcemeat in smoked sausages. Scientific Messenger of Lviv National University of Veterinary Medicine and Biotechnologies, 20(83), 268-273. doi: 10.15421/nvlvet8353.

Ukrainets, A., Pasichnyi, V., Shvedyuk, D., Matsuk, Y. (2017). Investigation of proteolysis ability of functional destinated minced half-finished meat products. Scientific Messenger LNUVMBT named after S.Z. Gzhytskyj, 19(75), 129-133. doi: 10.15421/nvlvet7526.

Volik, V.G., Ismailova, D.Ju., \& Erohina, O.N. (2011). Jeffektivnoe ispol'zovanie vtorichnogo syr'ja, poluchaemogo pri pererabotke pticy. Ptica i pticeprodukty, 3, 16-20. http://webpticeprom.ru/download/articles/ 24.01.2012.pdf (in Russian). 